\title{
Article \\ Changes in Epigenetic Patterns Related to DNA Replication in Vicia faba Root Meristem Cells under Cadmium-Induced Stress Conditions
}

\author{
Aneta Żabka ${ }^{1, *(D)}$, Natalia Gocek ${ }^{1}$, Konrad Winnicki ${ }^{1}$ (D), Paweł Szczeblewski ${ }^{2}$, Tomasz Laskowski ${ }^{2}$ (D) \\ and Justyna Teresa Polit ${ }^{1}$ (D) \\ 1 Department of Cytophysiology, Faculty of Biology and Environmental Protection, University of Lodz, \\ 90-236 Lodz, Poland; natalia.gocek@edu.uni.lodz.pl (N.G.); konrad.winnicki@biol.uni.lodz.pl (K.W.); \\ justyna.polit@biol.uni.lodz.pl (J.T.P.) \\ 2 Department of Pharmaceutical Technology and Biochemistry, Faculty of Chemistry, Gdansk University of \\ Technology, 80-233 Gdansk, Poland; pawel.szczeblewski@pg.edu.pl (P.S.); tomasz.laskowski@pg.edu.pl (T.L.) \\ * Correspondence: aneta.zabka@biol.uni.lodz.pl; Tel.: +48-428-354-512
}

check for

updates

Citation: Żabka, A.; Gocek, N.; Winnicki, K.; Szczeblewski, P.; Laskowski, T.; Polit, J.T. Changes in Epigenetic Patterns Related to DNA Replication in Vicia faba Root Meristem Cells under CadmiumInduced Stress Conditions. Cells 2021, 10, 3409. https://doi.org/10.3390/ cells10123409

Academic Editor: Keqiang Wu

Received: 4 October 2021

Accepted: 22 November 2021

Published: 3 December 2021

Publisher's Note: MDPI stays neutral with regard to jurisdictional claims in published maps and institutional affiliations.

Copyright: (C) 2021 by the authors. Licensee MDPI, Basel, Switzerland. This article is an open access article distributed under the terms and conditions of the Creative Commons Attribution (CC BY) license (https:/ / creativecommons.org/licenses/by/ $4.0 /)$.
Abstract: Experiments on Vicia faba root meristem cells exposed to $150 \mu \mathrm{M}$ cadmium chloride $\left(\mathrm{CdCl}_{2}\right)$ were undertaken to analyse epigenetic changes, mainly with respect to DNA replication stress. Histone modifications examined by means of immunofluorescence labeling included: (1) acetylation of histone $\mathrm{H} 3$ on lysine 56 (H3K56Ac), involved in transcription, $\mathrm{S}$ phase, and response to DNA damage during DNA biosynthesis; (2) dimethylation of histone H3 on lysine 79 (H3K79Me2), correlated with the replication initiation; (3) phosphorylation of histone H3 on threonine 45 (H3T45Ph), engaged in DNA synthesis and apoptosis. Moreover, immunostaining using specific antibodies against 5-MetCmodified DNA was used to determine the level of DNA methylation. A significant decrease in the level of $\mathrm{H} 3 \mathrm{~K} 79 \mathrm{Me} 2$, noted in all phases of the $\mathrm{CdCl}_{2}$-treated interphase cell nuclei, was found to correspond with: (1) an increase in the mean number of intranuclear foci of H3K56Ac histones (observed mainly in S-phase), (2) a plethora of nuclear and nucleolar labeling patterns (combined with a general decrease in $\mathrm{H} 3 \mathrm{~T} 45 \mathrm{Ph}$ ), and (3) a decrease in DNA methylation. All these changes correlate well with a general viewpoint that DNA modifications and post-translational histone modifications play an important role in gene expression and plant development under cadmium-induced stress conditions.

Keywords: cadmium; DNA methylation; DNA replication; epigenetic modifications; H3K56Ac; H3K79Me2; H3T45Ph; replication stress; transcription; Vicia faba

\section{Introduction}

Due to a sedentary lifestyle, plants are constantly exposed to a variety of environmental stresses which largely hinder their proper development. In addition to a number of biotic factors, e.g., pathogens, pests, or plant competitiveness, many abiotic stressors, such as too high or low temperature, severe shortage of water, lack or excess of minerals, salinity, intense solar radiation, and heavy metals, represent significant limiting factors for plants' growth and productivity [1-3]. Therefore, in order to prevent stressful situations, plants have developed complicated and complex mechanisms for stress detection and defense reactions [4]. Accordingly, they activate various signal transduction pathways to allow the expression of stress-responsive genes, which ultimately induce changes at the morphological, physiological, and biochemical levels that adapt plants to adverse environmental conditions [5,6].

The mechanism of genome-wide DNA duplication precisely carries out its functions despite numerous obstacles of intracellular and extracellular origin, many of which can lead to "replication stress" (RS). It is well known that there are many sources of RS and, thus, its definition is constantly evolving and difficult to formulate. Currently, we define RS as slowing down or stopping the movement of replication forks and/or DNA synthesis. Since 
DNA synthesis, as well as the cellular response to RS, occur in the context of chromatin, histone dynamics play a key role in modulating fork progression $[7,8]$. It is known that DNA replication requires simultaneous separation and reassembly of chromatin, and prolonged disruption and/or inhibition of replication carries a high risk of altering the newly formed chromatin in a way that may alter epigenetic information; these, in turn, may affect gene regulation and the spatial organization of DNA [9].

Heavy metals (HMs) are natural components present throughout the earth's crust and are characterized by a relatively high atomic mass and high density [10]. HMs can be divided into two groups: (i) elements necessary for the proper growth and development of plants, such as cobalt $(\mathrm{Co})$, copper $(\mathrm{Cu})$, zinc $(\mathrm{Zn})$, magnesium $(\mathrm{Mg})$, molybdenum $(\mathrm{Mo})$, nickel $(\mathrm{Ni})$, copper $(\mathrm{Cu})$, and selenium $(\mathrm{Se})$, which regulate enzymatic functions and (ii) non-essential elements of recognized toxicity, such as lead (Pb), cadmium (Cd), or chromium (Cr) [3,11,12]. While the first group of elements (in small amounts) is important and necessary for the life cycle of plants, high concentrations of both types of HMs are very dangerous. They induce cytotoxic, genotoxic, and mutagenic effects, which may lead to inhibition of plant growth, reduction in nutrient uptake, and, ultimately, to chlorosis and necrosis [3].

HM poisoning in plants brings about an increased production of reactive oxygen species (ROS), which results in oxidative stress (OS) and a consequent lipid peroxidation, membrane breakdown, biological destruction of macromolecules, cell wall injury, ion leakage, and DNA damage [13-15]. One of the defence strategies used by plants against HMs is aimed at the strengthening of the antioxidant systems that can counteract OS [13,16]. Another defence mechanism adopted by plants relies on the hindered penetration of HMs by binding them to organic acids, thus trapping them in an apoplastic environment [17], or by anionic groups present in the cell walls of the roots $[18,19]$. In consequence, most of the HMs entering plants are detoxified as a result of complexation with amino acids, organic acids, or metal-binding peptides [20]. This, in turn, significantly hinders the translocation of HMs absorbed by plant ground organs [11].

DNA repair and replication involve the incorporation of newly synthesized histones to restore the functional chromatin environment [21]. An important aspect during these processes is the epigenetic modification of newly synthesized histones before their incorporation into chromatin. Posttranslational modifications of histone $\mathrm{H} 3$ are one of the most extensive epigenetic changes that occur among the four core histones. Generally, attention has been paid to the phosphorylation at a conserved serine residue (Ser10) in the N-terminal tail of histone H3 (H3S10), which is linked to both activation of transcription [22] and to mitotic and meiotic chromosome condensation [23-25]. Furthermore, histone $\mathrm{H} 3$ acetylations, primarily at lysine 9 (H3K9), 14 (H3K14), and 27 (H3K27), were observed to be enriched near the transcription start sites and in transcribed promoters associated with active transcription $[26,27]$. The newly synthesized molecules of $\mathrm{H} 3$ histones undergo acetylation prior to deposition on DNA, and the preferential acetylation sites differ between species (e.g., H3K56Ac in budding yeast or H3K14Ac and H3K18Ac in human cells [28]). Acetylation helps to attenuate histone H1 deposition and thus prevents chromatin thickening during the replication process [29]. The acetylation of histone $\mathrm{H} 3$ on lysine 56 (H3K56Ac) is recognized as a marker of newly synthesized H3 molecules [21,30].

In addition to H3K56 acetylation, one of the best-known fingerprints of the double strand breaks (DSBs) is phosphorylation of histone H2AX on Ser139 ( $\gamma$-H2AX). RS triggers a set of cellular signaling mechanisms to single and double stranded DNA damage sites at stalled or slowed down replication forks. Using $\gamma-\mathrm{H} 2 \mathrm{AX}$ immunofluorescence labeling, our previous experiments [31] showed an increased number of visible $\gamma$-H2AX foci in $V$. faba cells exposed to $24 \mathrm{~h}$ incubation with $\mathrm{CdCl}_{2}$ and a decreased level of $\mathrm{H} 2 \mathrm{AX}$ phosphorylation in the control root cells (after post-cadmium recovery in water). While $\gamma-\mathrm{H} 2 \mathrm{AX}$ is primarily a DSBs marker, ample evidence points to a more general role of $\gamma-\mathrm{H} 2 \mathrm{AX}$ during RS, both in inhibiting replication forks in the absence of DSBs and in repairing collapsed replication forks [9]. Moreover, inhibition or delay of cell cycle progression may extend the time 
necessary for the initiation of gene expression related to the synthesis and activation of DNA damage repair factors [32,33].

While some studies have shown that H3K56 acetylation is involved in transcription [34,35], other data proved that it is also involved in the response to DNA damage during replication [21,36-38]. Confirmation of this important function during DNA biosynthesis is supported by the fact that H3K56Ac levels increase during the $\mathrm{S}$ phase and largely decline during the G2/M phase [21].

Another type of epigenetic modification involved in the control of transcriptional elongation, DNA replication, DNA repair, and heterochromatin maintenance is represented by differential mono-, di-, and tri-methylation of $\mathrm{H} 3$ histone at lysine $\mathrm{K} 79$ (H3K79Me, H3K79Me2, and H3K79Me3). H3K79Me2 was shown to exhibit the highest genome-wide enrichment for replication initiation events observed for any chromatin modification [39]. Accordingly, it seems probable that the prevention of H3K79 dimethylation affects regulatory processes which are responsible for modulating the order and timing of DNA replication. Moreover, H3K79Me2 associates with some replication origins and marks replicated chromatin during the S-phase to prevent re-replication and preserve genomic stability.

Our present studies on Vicia faba root meristem cells aimed to analyse and to update our understanding of issues related to changes in epigenetic patterns after exposure to one of the heavy metals-cadmium $\left(\mathrm{CdCl}_{2}\right)$. DNA methylation patterns and $\mathrm{H} 3$ histone modifications examined by means of immunofluorescence labeling, related mainly to the process of DNA replication, included: (i) acetylation of histone $\mathrm{H} 3$ on lysine 56 (H3K56Ac), a process involved in transcription [34,35], $\mathrm{S}$ phase transition [30], and in the response to DNA damage during DNA biosynthesis [21,36,37,40,41]; (ii) the dimethylation of histone $\mathrm{H} 3$ on lysine 79 (H3K79Me2), which is correlated with the replication initiation sites [39]; (iii) the phosphorylation of histone $\mathrm{H} 3$ on threonine 45 (H3T45Ph), which is involved in DNA replication and apoptosis [42,43].

\section{Materials and Methods}

\subsection{Plant Material}

Sterile seeds of field bean (Vicia faba L. subsp. minor) were sown in trays, lined with moist blotting paper, and germinated in the dark at $20^{\circ} \mathrm{C}$. After $72 \mathrm{~h}$, plants with roots approximately $2.5 \mathrm{~cm}$ long were placed in distilled water (control) and $150 \mu \mathrm{M} \mathrm{CdCl}_{2}$ solution. The concentration of $\mathrm{CdCl}_{2}$ was selected based on the available literature data, e.g., $[44,45]$, based on the results obtained in a series of preliminary tests and applied in earlier studies [31]. Cultures were aerated by gentle rotation of Petri dishes in a water-bath shaker (60 r.p.m.), performed for $24 \mathrm{~h}$ in the dark.

\subsection{Feulgen Staining and DNA Cytophotometry}

Apical root fragments were fixed for $60 \mathrm{~min}$ in cold Carnoy's mixture (absolute ethanol and glacial acetic acid; 3:1, v/v). After washing with ethanol (3 times), root tips were rehydrated, hydrolysed for $1 \mathrm{~h}$ in $4 \mathrm{M} \mathrm{HCl}$, and Feulgen-DNA-stained using the standard method [46] with pararosaniline (applied to selectively stain DNA in a quantitative colorimetric measurement of aldehydes in the Schiff's test; Sigma-Aldrich, Poznan, Poland). Following 3 times rinsing with $\mathrm{SO}_{2}$ water (sulphurous acid prepared from sodium metabisulphite and dilute $\mathrm{HCl}$ to stop Feulgen staining, to fix the color, and to elute unbound molecules) and after washing with distilled water, root tips were crushed on microscope slides in $45 \%$ acetic acid. Squash preparations were frozen on dry ice, dried, and embedded in Canadian balsam. The total number of cells analysed was always 8000 (out of 10 root meristems) at each time point. Selected cells were photographed with E-600 epifluorescence microscope (Nikon). The extinction of Feulgen-stained cell nuclei was measured at $565 \mathrm{~nm}$ with a Jenamed 2 microscope (Carl Zeiss, Jena, Germany) and calibrated in arbitrary units (a.u.). A computer system (Forel, Łódź, Poland) was used for image analysis. Approximately 5000 nuclei were collected to evaluate the distribution of the DNA content. 
2.3. Immunocytochemical Detections of Dimethylation of Histone H3 on Lysine 79 (H3K79Me2), Acetylation of Histone H3 on Lysine 56 (H3K56Ac), and Phosphorylation of Histone H3 on Threonine 45 (H3T45Ph)

Root meristems from $V$. faba cuttings were fixed $\left(20 \mathrm{~min}, 20^{\circ} \mathrm{C}\right)$ in PBS (PhosphateBuffered Saline)-buffered 3.7\% paraformaldehyde; then, cell nuclei were isolated, dropped onto glass slides, and air dried (procedure according to [31]). After rinsing thoroughly with PBS, apical parts of roots were crushed on Super Frost Plus slides, dried, and pre-treated with PBS-buffered 8\% BSA and 4\% Triton X-100 (Sigma-Aldrich, Poznan, Poland) for $50 \mathrm{~min}$ $\left(20{ }^{\circ} \mathrm{C}\right)$. Then, slides were incubated with:

(1) rabbit polyclonal anti-histone H3K79Me2 antibodies (Abcam, dilution of 1:200);

(2) rabbit monoclonal anti-histone H3K56Ac antibodies (Abcam, dilution of 1:200);

(3) rabbit polyclonal anti-histone $\mathrm{H3T45Ph}$ antibodies (Abcam, dilution of 1:100).

All antibodies were dissolved in PBS containing 1\% BSA. Incubations were carried out in a humid atmosphere at $4{ }^{\circ} \mathrm{C}$ for $16 \mathrm{~h}$. After washing with PBS, slides were incubated for $1 \mathrm{~h}\left(20^{\circ} \mathrm{C}\right)$ with secondary goat anti-rabbit conjugated to Alexa Fluor ${ }^{\circledR} 488$ antibodies (1:500; Cell Signaling, Warsaw, Poland) and counterstained with PI (propidium iodide; $\left.0.3 \mathrm{mg} \mathrm{mL}^{-1}\right)$. Slides washed with PBS were air dried and embedded in PBS mixture/glycerol (9:1) with $2.3 \%$ DABCO.

\subsection{Immunocytochemical Staining for DNA Methylation}

Cut root meristems of the control and $\mathrm{CdCl}_{2}$-treated seedlings were fixed for $20 \mathrm{~min}$ at $4^{\circ} \mathrm{C}$ in freshly prepared $4 \%$ paraformaldehyde. After fixation, root tips were washed with distilled water, then cell nuclei were isolated, dropped onto glass slides, and air dried. Slides were treated with $4 \mathrm{M} \mathrm{HCl}$ for $1.5 \mathrm{~h}$ to partially denature the nuclear DNA (room temperature), washed with Tris buffer ( $\mathrm{pH} 7.4$ ) containing $0.5 \%$ Triton $\mathrm{X}-100$, and incubated with mouse monoclonal anti-5-methylcytosine antibodies (5-MetC, Sigma-Aldrich, Poznan, Poland) diluted in Tris buffer (1:100). After $16 \mathrm{~h}\left(4^{\circ} \mathrm{C}\right)$, slides were washed (Tris buffer) and incubated for $1 \mathrm{~h}$ with secondary goat anti-rabbit antibodies conjugated to the bright, green-fluorescent dye Alexa Fluor ${ }^{\circledR} 488$ (1:500; Cell Signaling, Warsaw, Poland), washed in Tris buffer, and embedded in PBS mixture/glycerol with DABCO.

\subsection{Observations and Analyses}

Fluorescence intensity analyses, the line plots, and Interactive 3D Surface Plots were performed with the ImageJ software (v1.8.0). Observations were made using E-600 epifluorescence microscope (Nikon) equipped with phase-contrast optics, U2 filter (UVB light; $\lambda=340-380 \mathrm{~nm}$ ) for DAPI, B2 filter (blue light; $\lambda=465-496 \mathrm{~nm}$ ) for Alexa Fluor ${ }^{\circledR} 488$, and G2 filter (green light; $\lambda=540 / 25 \mathrm{~nm}$ ) for PI-stained cell nuclei. All quantitative analyses and nuclear DNA fluorescence measurements were made after converting colour images into greyscale images and were expressed in arbitrary units as mean pixel value (pv) spanning the range from 0 (dark) to 255 (white). The obtained data were expressed as the mean values \pm standard deviation (SD). Student's $t$-tests for paired data were used to compare individual variables. Results used to calculate mean values and micrographs were obtained from one out of three independent experiments (all of them have provided similar sets of data).

\section{Results}

\subsection{Effect of $\mathrm{CdCl}_{2}$ on Chromatin Condensation and Root Meristem Cell Cycle Populations}

Microscopic images of the interphase cell nuclei from the $\mathrm{CdCl}_{2}$-treated root meristems revealed evident changes in the chromatin structure. In comparison with the control plants, DNA-Feulgen staining showed strong condensation of chromatin, blurring the natural diversity of its fibrillar structures and a distinct, spotted pattern of heterochromatin (Figure 1A). 

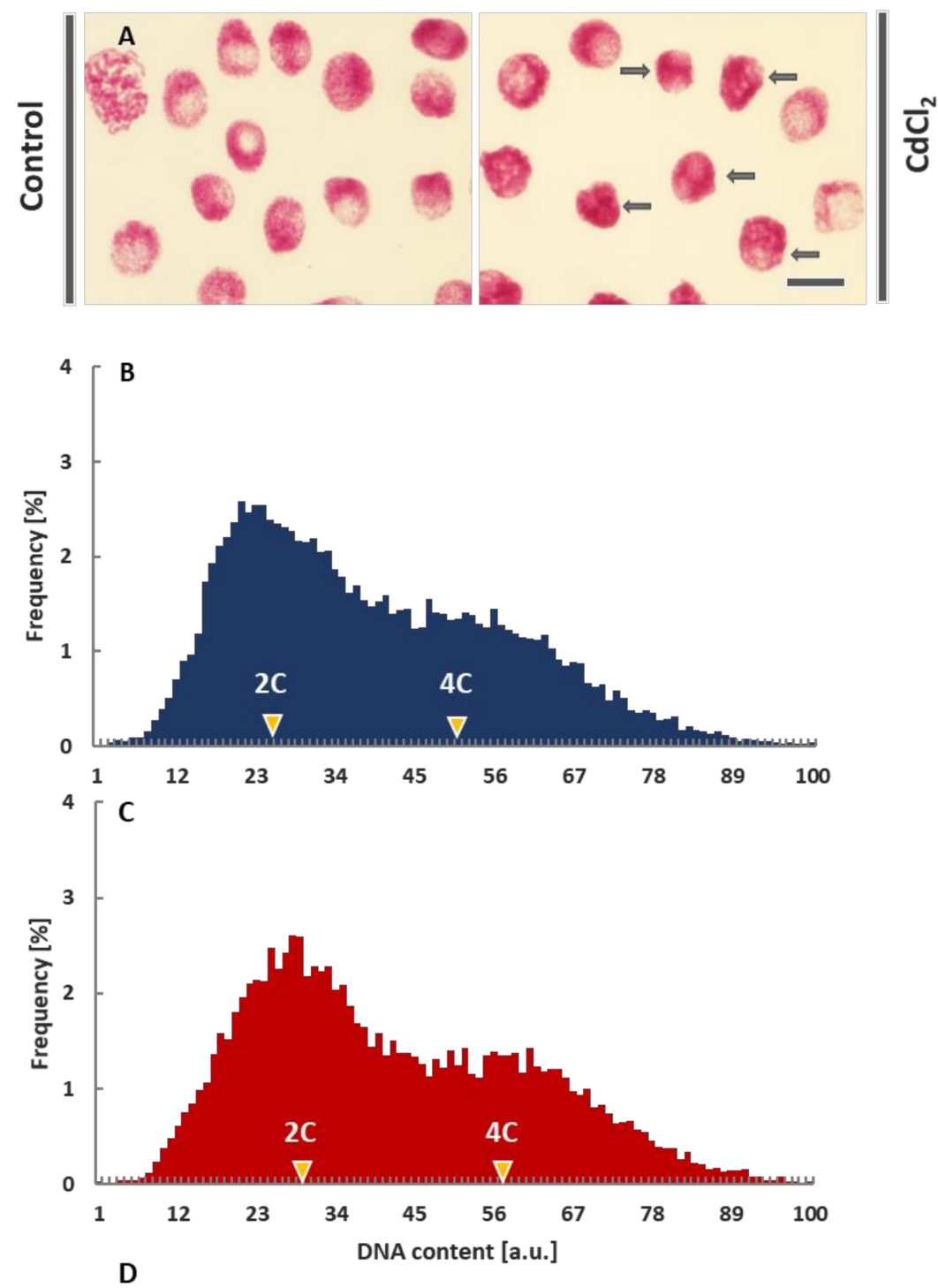

\begin{tabular}{|c|c|c|}
\hline $\begin{array}{c}\text { Cell cycle } \\
\text { phase }\end{array}$ & Control & $\mathbf{C d C l}_{\mathbf{2}}$ \\
\hline $\mathbf{G 1 + 1 / 2 M}$ & $26.1 \%$ & $30.1 \%$ \\
\hline $\mathbf{S}$ & $41.7 \%$ & $44.8 \%$ \\
\hline $\mathbf{G 2 + 1 / 2 M}$ & $32.2 \%$ & $25.1 \%$ \\
\hline
\end{tabular}

Figure 1. Feulgen-DNA staining of $V$. faba cell nuclei from the control root meristems and after incubation with $\mathrm{CdCl}_{2}$ (scale bar $=20 \mu \mathrm{m}$ ); arrows in the micrographs (A) show cell nuclei with significantly condensed chromatin. Histograms of frequency distribution of nuclear DNA content (arbitrary units, au) in control meristems (B) and after 24-h incubation of root meristems with $\mathrm{CdCl}_{2}$ (C). Each population consisted of more than 18,000 cell nuclei. The table below the histograms (D) shows estimated frequencies (\%) of G1+ $\frac{1}{2} \mathrm{M}$ phase cell nuclei (including of ana- and telophases), $\mathrm{S}$ phase cell nuclei, and G2+1/2M phase cell nuclei (including pro- and metaphases) in the control and $\mathrm{CdCl}_{2}$-treated root meristems. 
Cytophotometric measurements of nuclear DNA content revealed quite similar quantities of 2C (G1-phase), 2-4C (S-phase), and 4C (G2-phase) cells both in the control (Figure 1B; dark blue histogram) and $\mathrm{CdCl}_{2}$-treated plants (Figure $1 \mathrm{C}$; dark red histogram). After the application of $\mathrm{CdCl}_{2}$, a slight shift to the right of the maximum values for the G1and G2-phase cell cycle subpopulations was observed. This result is probably due to the increased level of chromatin condensation. It can be noted (Figure 1D) that an increase in the number of the $\mathrm{G} 1$ phase cells in $\mathrm{CdCl}_{2}$-treated roots (30.1\% compared to $26.1 \%$ in the control) is accompanied by a slight increase in the number of cells in the S (44.8\% compared to $41.7 \%$ ) and a more significant rise in the number of G2 phase cells ( $25.1 \%$ compared to $32.2 \%$; Figure 1B-D).

\subsection{Dimethylation of Histone H3 on Lysine 79 (H3K79Me2)}

Our previous experiments on $V$. faba root meristems treated with $150 \mu \mathrm{M} \mathrm{CdCl}_{2}$ showed that $\mathrm{H} 4$ acetylation of lysine 5 in nucleosomal histone H4 (H4K5Ac) is mainly related to DNA replication [31]. It was observed that the variable relationships between H4K5Ac acetylation and successive stages of the cell cycle were strongly modified by cadmium-induced stress conditions. In this work, microfluorimetric measurements were carried out towards evaluating the extent of histone $\mathrm{H} 3$ lysine 79 dimethylation (H3K79Me2) (Figure 2). The analyses included: (i) fluorescence intensity (FI) of the entire areas of cell nuclei (together with the nucleoli) during the G1, S, and G2 phases of the cell cycle; (ii) FI of the nuclear chromatin (excluding the nuclear area) and of the nucleoli. Numerous small foci were observed in cell nuclei derived from the control meristems (Figure 2A-B'). The nucleoli were often surrounded by a circle of dots (Figure 2A). In the case of cadmium-treated plants, the foci of fluorescence were also revealed, although they were less numerous than in the control (Figure 2C,D). Another difference that can be observed in the case of $V$. faba seedlings incubated with $\mathrm{CdCl}_{2}$ is the much stronger fluorescence of the nucleolar regions (visible against the background of much less fluorescent areas of the extranucleolar chromatin; Figure 2C- $\left.\mathrm{D}^{\prime}\right)$. As compared with the control, a significant decrease in the level of nuclear fluorescence was noted in all phases of the $\mathrm{CdCl}_{2}$-treated interphase cell nuclei (Figure 2E), both in the area of the nuclear chromatin and nucleolus (Figure 2F). The differences in the structure of the nucleus and the nucleolus can be seen in the line plots shown in Figure $2 \mathrm{~A}^{\prime}-\mathrm{D}^{\prime}$.

\subsection{Acetylation of Histone H3 on Lysine 56 (H3K56Ac)}

Using specific antibodies, we analysed another modification-acetylation of histone $\mathrm{H} 3$ on lysine 56 (H3K56Ac). We found that, both in the control and $\mathrm{CdCl}_{2}$-treated roots, $\mathrm{H} 3 \mathrm{~K} 56 \mathrm{Ac}$ is distributed in the nucleus and the nucleolus in a punctate (focal) pattern (Figure 3). The immunofluorescence analysis included: (i) the mean total number of intranuclear H3K56Ac foci during the G1, S, and G2 phases and (ii) the mean number of $\mathrm{H} 3 \mathrm{~K} 56 \mathrm{Ac}$ foci in the nuclear chromatin (excluding the nucleolar area) and in the nucleolus. In control roots, cell nuclei having 2, 2-4C, and 4C DNA content are characterized by the presence of fluorescing $\mathrm{H} 3 \mathrm{~K} 56 \mathrm{Ac}$ foci situated in the area of the nuclear chromatin (Figure $3 \mathrm{~A}-\mathrm{H}$ ) and, especially after treatment with $\mathrm{CdCl}_{2}$, at the border of the nucleolus and perinucleolar chromatin (Figure 3F,G). Moreover, quantitative analyses, including Interactive 3D Surface Plots, revealed a greater number of so-called peaks (corresponding to $\mathrm{H} 3 \mathrm{~K} 56 \mathrm{Ac}$ foci) in the nuclei of meristematic cells incubated in $\mathrm{CdCl}_{2}$ (Figure $\left.3 \mathrm{E}^{\prime}-\mathrm{H}^{\prime}\right)$. 

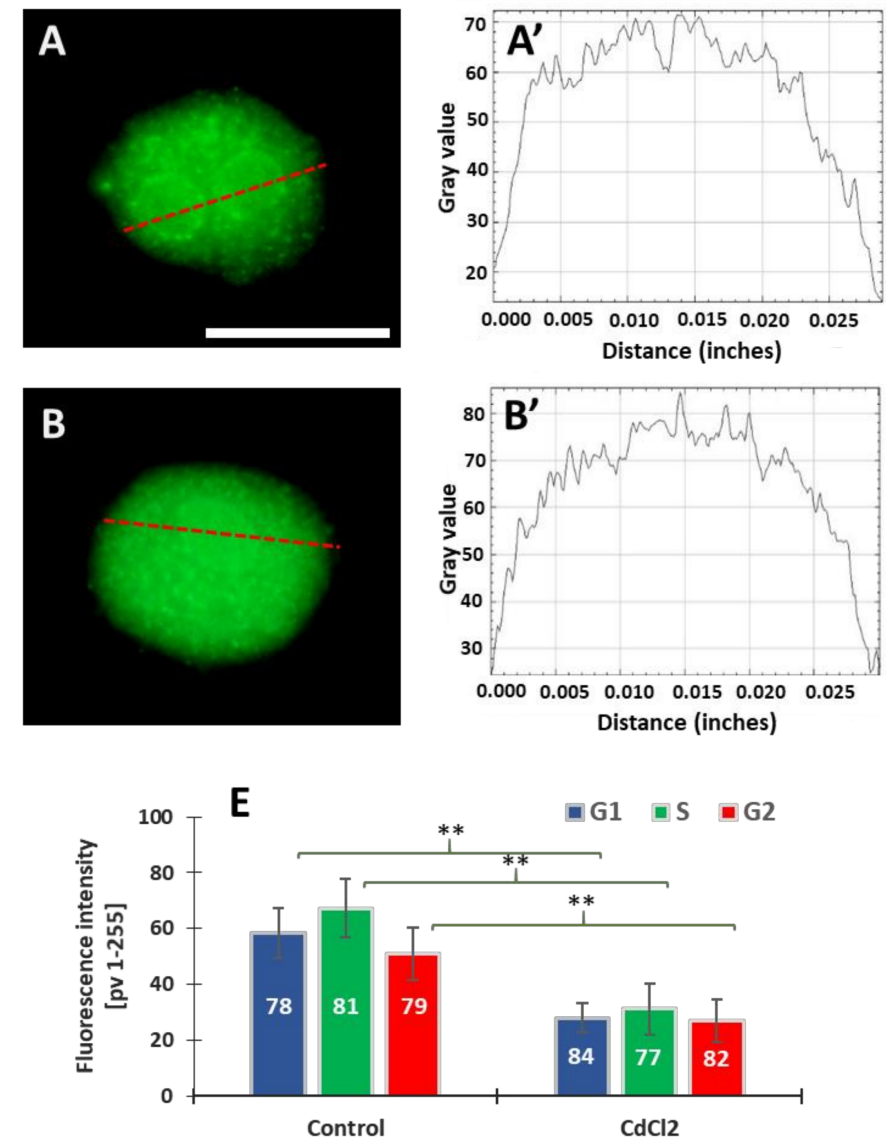
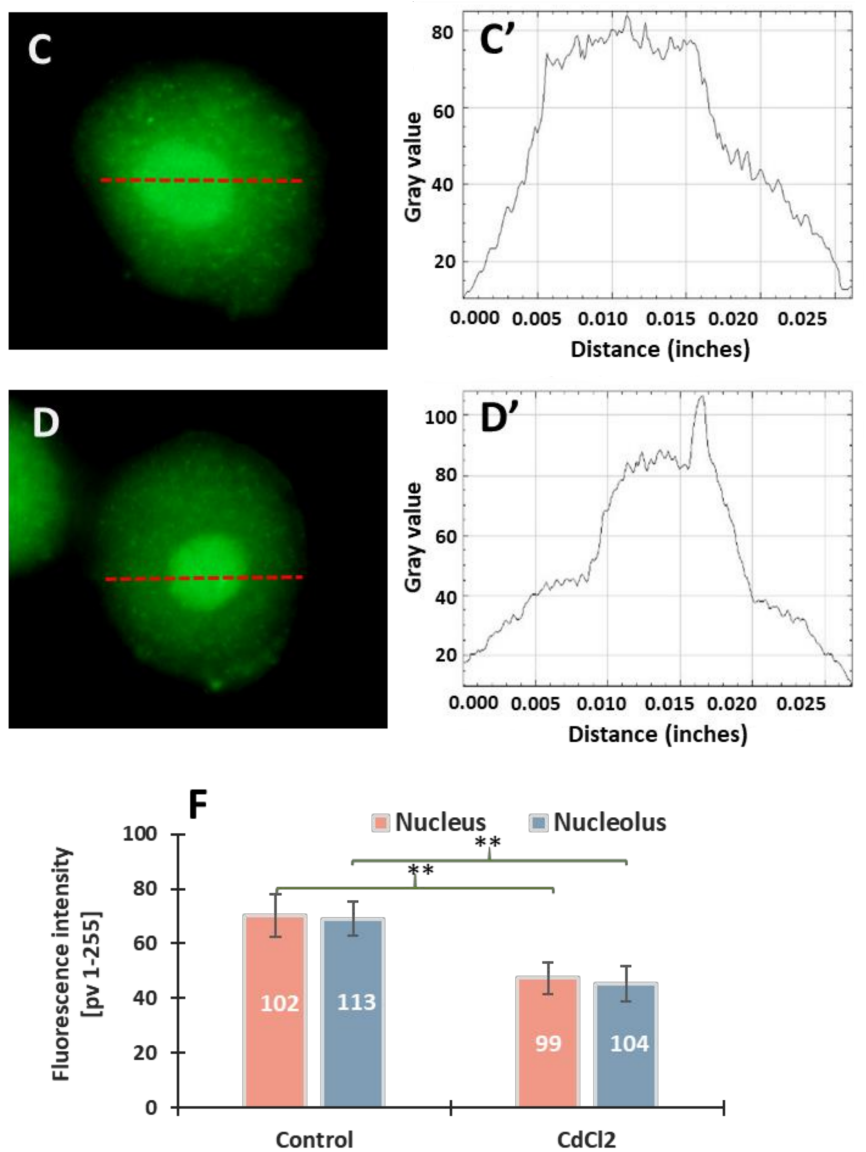

Figure 2. Immunofluorescence detection of $\mathrm{H} 3 \mathrm{~K} 79 \mathrm{Me} 2$ in the $V$. faba cell nuclei (represented by the G2 phase), from the control $(\mathbf{A}, \mathbf{B})$ and $\mathrm{CdCl}_{2}$-treated seedlings $((\mathbf{C}, \mathbf{D})$; scale bar $=10 \mu \mathrm{m})$. Densitometric plots showing changes in the intensity of fluorescence of the nuclear and nucleolar regions in the control $\left(\mathbf{A}^{\prime}, \mathbf{B}^{\prime}\right)$ and after $\mathrm{CdCl}_{2}$ treatment $\left(\mathbf{C}^{\prime}, \mathbf{D}^{\prime}\right)$; the course of each plot is marked by a red dashed line. Mean FI of H3K79Me2 in the interphase cell nuclei (E) and mean FI of H3K79Me2 in the nuclear chromatin and nucleolar regions $(\mathrm{F})$ in the control and $\mathrm{CdCl}_{2}$-treated root meristem cells. Error bars represent standard deviation (SD). The numbers of cell nuclei/nucleoli used for immunostaining quantification are given inside the diagram bars. Statistical significance between mean values (at ${ }^{* *} p<0.01$, indicated by a black asterisks) was assessed with Student's $t$-test.

The data calculated for G1-, S-, and G2-cells indicate that $24 \mathrm{~h}$ incubation with $\mathrm{CdCl}_{2}$ results in an increase in the mean number of intranuclear foci of H3K56Ac histones; the highest, almost a 2-fold increase, was observed in the S-phase (Figure 3I). Results, averaged for all phases, show that the mean number of H3K56Ac foci in the nucleus increased from $16 \%$ in the control to $20 \%$ in $\mathrm{CdCl}_{2}$-treated cells (Figure 3J) and, at the same time, a 2.5 -fold increase in the mean number of H3K56Ac foci localized in the nucleolar area (Figure 3J).

\subsection{Phosphorylation of Histone $\mathrm{H} 3$ on Threoninie 45 (H3T45Ph)}

Control and cadmium-treated root meristem cells of $V$. faba were immunolabeled with anti-H3T45Ph antibody (Figures 4 and 5A-F) and the following parameters were evaluated: (i) fluorescence intensity (FI) of the entire areas of cell nuclei (together with the nucleoli) during G1, S, and G2 (Figure 5G); (ii) FI of the nuclear chromatin (excluding the nucleolar area) and the nucleolus (Figure $5 \mathrm{H}$ ). 

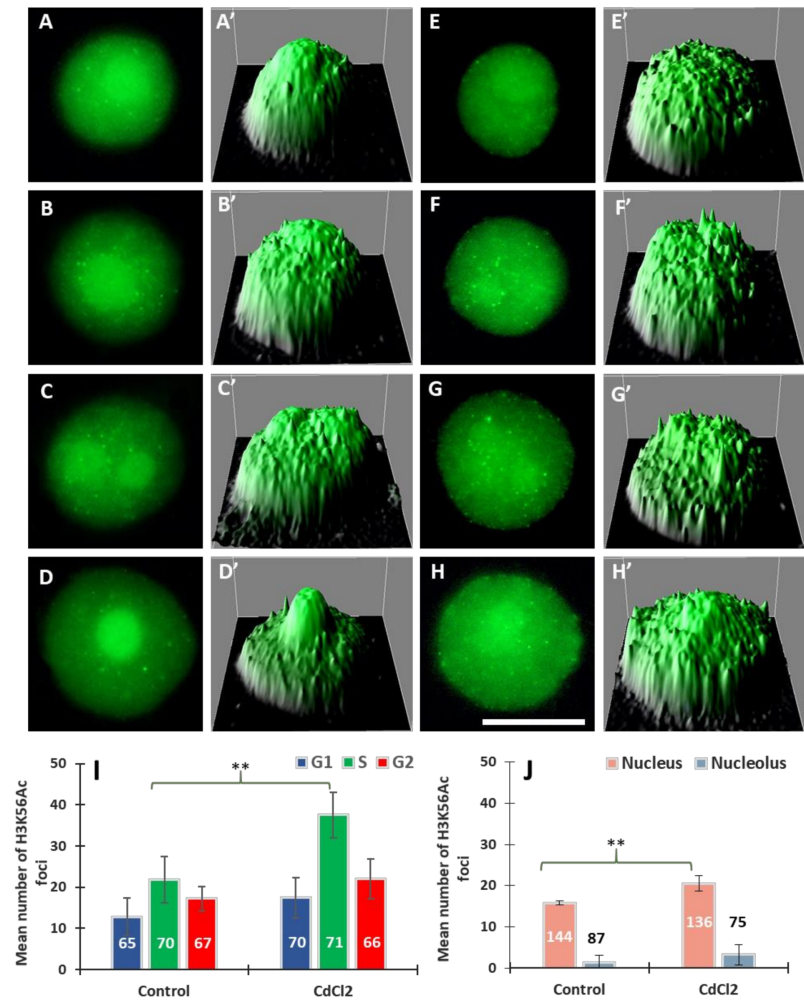

Figure 3. Immunofluorescence of $\mathrm{H} 3 \mathrm{~K} 56 \mathrm{Ac}$ in cell nuclei from the control (A-D) and $\mathrm{CdCl}_{2}$-treated root meristems $(\mathbf{E}-\mathbf{H})$ in the $\mathrm{G} 1(\mathbf{A}, \mathbf{E}), \mathbf{S}(\mathbf{B}, \mathbf{C}, \mathbf{F}, \mathbf{G})$, and $\mathrm{G} 2$ phases $(\mathbf{D}, \mathbf{H})$; scale bar $=10 \mu \mathrm{m}$. At the right side of each micrograph are corresponding interactive $3 \mathrm{D}$ surface plots $\left(\mathbf{A}^{\prime}-\mathbf{H}^{\prime}\right)$. Mean number of $\mathrm{H} 3 \mathrm{~K} 56 \mathrm{Ac}$ foci generated in $\mathrm{G} 1, \mathrm{~S}$, and G2 phase nuclei in the control and $\mathrm{CdCl}_{2}$-treated root meristem cells of $V$. faba, (I) and mean number of H3K56Ac foci in the nuclear and nucleolar chromatin from the control and $\mathrm{CdCl}_{2}$-treated root meristems $(\mathrm{J})$. Error bars represent standard deviation (SD). The numbers of cell nuclei used for immunostaining quantification are given inside or above the bars. Statistical significance between mean values (at ${ }^{* *} p<0.01$, indicated by a black asterisks) was assessed with Student's $t$-test.

Root meristem cells of $V$. faba stained with H3T45Ph antibody revealed a plethora of nuclear and nucleolar labeling patterns (Figure 4). In most cases, strong fluorescence of the nucleoli was combined with more or less intense staining of nuclear chromatin (Figure $4 \mathrm{~A}-\mathrm{E}^{\prime}$ in control and Figure $4 \mathrm{G}, \mathrm{G}^{\prime}$ in $\mathrm{CdCl}_{2}$-treated seedlings); the nucleoli were often surrounded by a circle of fluorescing dots (Figure $4 \mathrm{H}-\mathrm{I}^{\prime}$ ). Moreover, antigenic determinants of H3T45Ph proteins were found, localized within the internal areas of interphase chromatin (Figure $4 \mathrm{C}-\mathrm{K}^{\prime}$ ).

The line plots passing the nucleus throughout the nucleolar region revealed a significantly higher degree of fluorescence, mostly in the cadmium-treated seedlings (Figure $5 \mathrm{~A}^{\prime}-\mathrm{F}^{\prime}$ ), than that emitted by the extranucleolar chromatin region (Figure 5A-F). As compared to the control, the $24 \mathrm{~h}$ incubation with $\mathrm{CdCl}_{2}$ resulted in a $20 \%$ decrease in $\mathrm{FI}$ in the $\mathrm{G} 1, \mathrm{~S}$, and G2 phases of the cell cycle (Figure 5G). The second analysis revealed a decrease of about $15 \%$ in the FI values calculated both for the nuclear and nucleolar chromatin (Figure $5 \mathrm{H}$ ). 


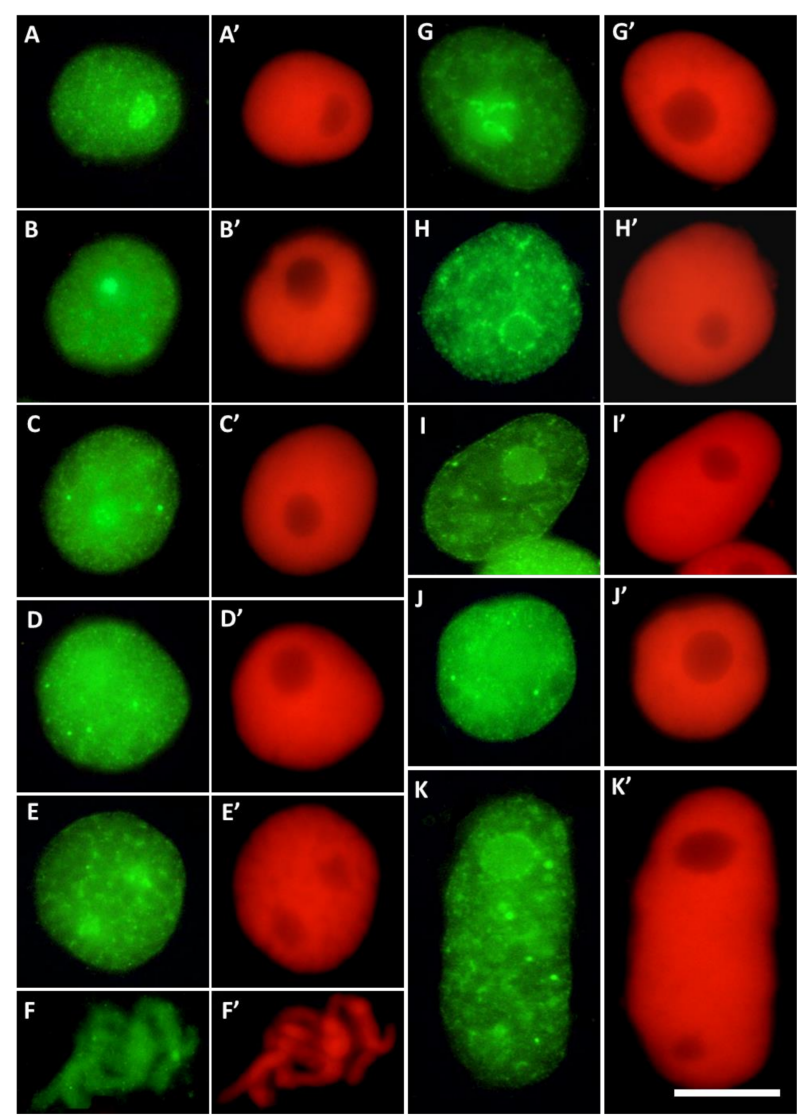

Figure 4. Different labeling patterns observed in cell nuclei after immunostaining with antibodies against H3T45Ph conjugated with Alexa Fluor ${ }^{\circledR} 488$ ((A-K); green fluorescence) and corresponding images of cell nuclear DNA stained with propidium iodide $\left(\left(\mathbf{A}^{\prime}-\mathbf{K}^{\prime}\right)\right.$; red fluorescence). The control cells $\left(\mathbf{A}-\mathbf{F}^{\prime}\right)$ revealed predominant nucleolar staining of H3T45Ph $\left(\mathbf{A}-\mathbf{B}^{\prime}\right)$, localization of H3T45Ph within the internal areas of interphase chromatin $\left(\mathbf{C}-\mathbf{D}^{\prime}\right)$ and prophase $\left(\mathbf{E}, \mathbf{E}^{\prime}\right)$, and labeling of the chromosomal areas corresponding to the nucleolus-organizing regions (NORs) during prometaphase $\left(\mathbf{F}, \mathbf{F}^{\prime}\right)$. The $\mathrm{CdCl}_{2}$-treated cells show predominant nucleolar staining in cell nuclei $\left(\mathrm{G}, \mathrm{G}^{\prime}\right)$, specific labeling around nucleoli $\left(\mathbf{H}-\mathbf{I}^{\prime}\right)$, and localization of $\mathrm{H} 3 \mathrm{~T} 45 \mathrm{Ph}$ within the internal areas of interphase chromatin $\left(\mathbf{J}-\mathbf{K}^{\prime}\right)$.

\subsection{Immunocytochemical Detection of 5-Methylcytosine (5-MetC)}

The distribution and levels of methylated DNA (5-methylcytosine; 5-MetC) were observed in the entire areas of cell nuclei (together with the nucleoli) in both the control and $\mathrm{CdCl}_{2}$-treated root meristems of $V$. faba.

Compared to the control (Figure 6A-D), the intensity of 5-MetC immunofluorescence in roots exposed to cadmium (Figure $6 \mathrm{E}-\mathrm{G}$ ) decreased by about $30 \%$ (Figure $6 \mathrm{H}$ ). It was noted that the regions of significantly increased fluorescence throughout the interphase correspond with the margins of the nucleoli, quite often visible as a ring of smaller or larger dots (Figure 6A-F). In the mitotic stages, especially in the root meristem cells treated with $\mathrm{CdCl}_{2}$ (Figure 7), the chromosomes show particularly strong fluorescence signal in the form of bands (in different parts of the chromosome arms), localized in the pericentromeric and intercalary regions (Figure 7A-D). 

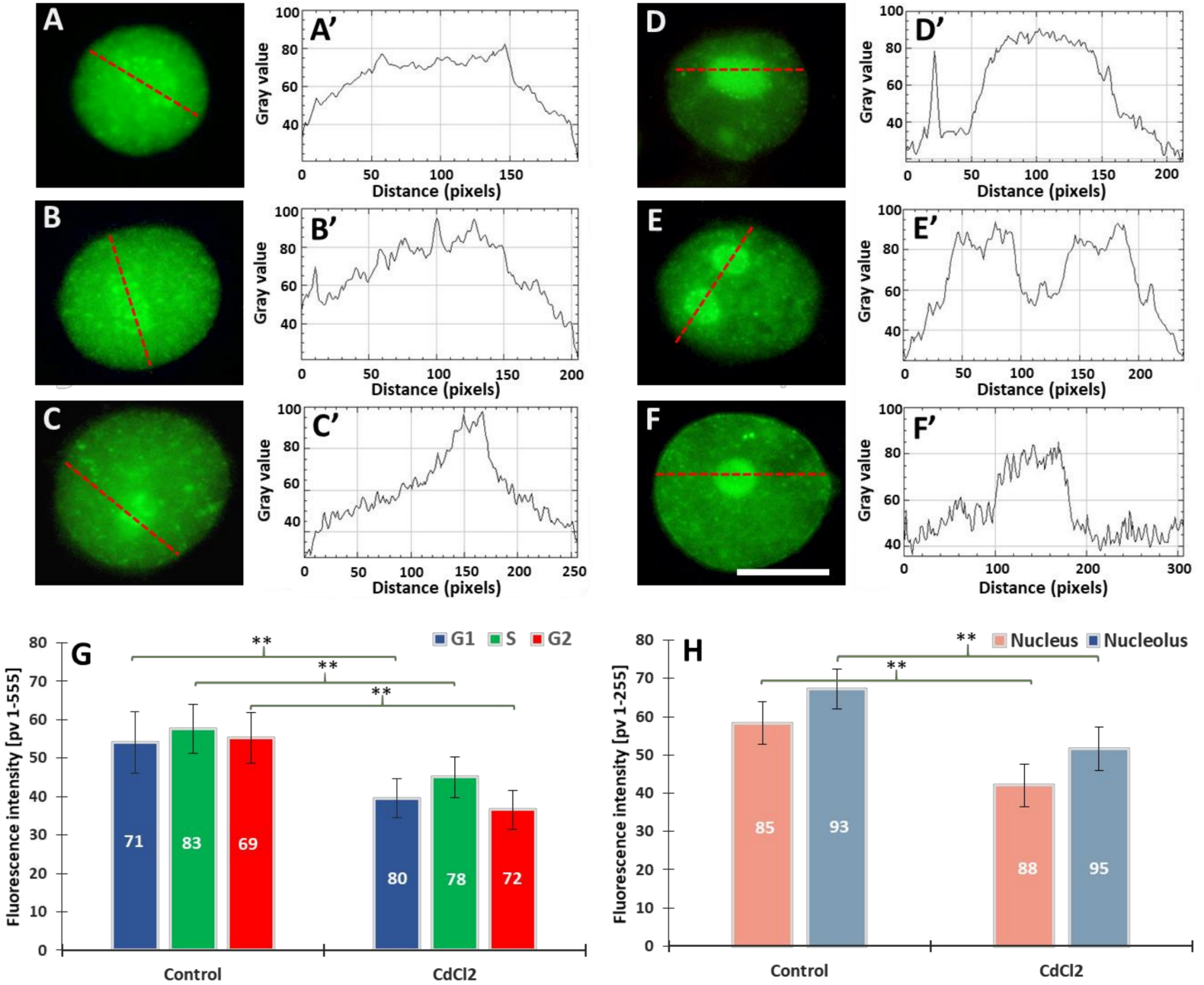

Figure 5. Immunofluorescence detection of $\mathrm{H} 3 \mathrm{~T} 45 \mathrm{Ph}$ in cell nuclei from the control $(\mathbf{A}-\mathrm{C})$ and $\mathrm{CdCl}_{2}$-treated seedlings of $V$. faba (D-F), in the G1 (A,D), S (B,E), and G2 phases (C,F); scale bar $=10 \mu \mathrm{m}$. Densitometric plots showing changes in fluorescence in the nuclear and nucleolar regions in the control $\left(\mathbf{A}^{\prime}-\mathbf{C}^{\prime}\right)$ and after treatment with $\mathrm{CdCl}_{2}\left(\mathbf{D}^{\prime}-\mathbf{F}^{\prime}\right)$; the course of each plot is marked by a red dashed line. Mean H3T45Ph fluorescence intensity of G1, S, and G2 phase nuclei in the control and $\mathrm{CdCl}_{2}$-treated root meristem cells $(\mathrm{G})$ and mean intensity of H3T45Ph fluorescence of the nuclear and nucleolar chromatin in the control and $\mathrm{CdCl}_{2}$-treated root meristems $(\mathbf{H})$. Error bars represent standard deviation (SD). The numbers of cell nuclei/nucleoli used for immunostaining quantification are given inside the bars. Statistical significance between mean values for the intensities of H3T45Ph fluorescence (at ${ }^{* *} p<0.05$, indicated by a black asterisks) was assessed with Student's $t$-test. 


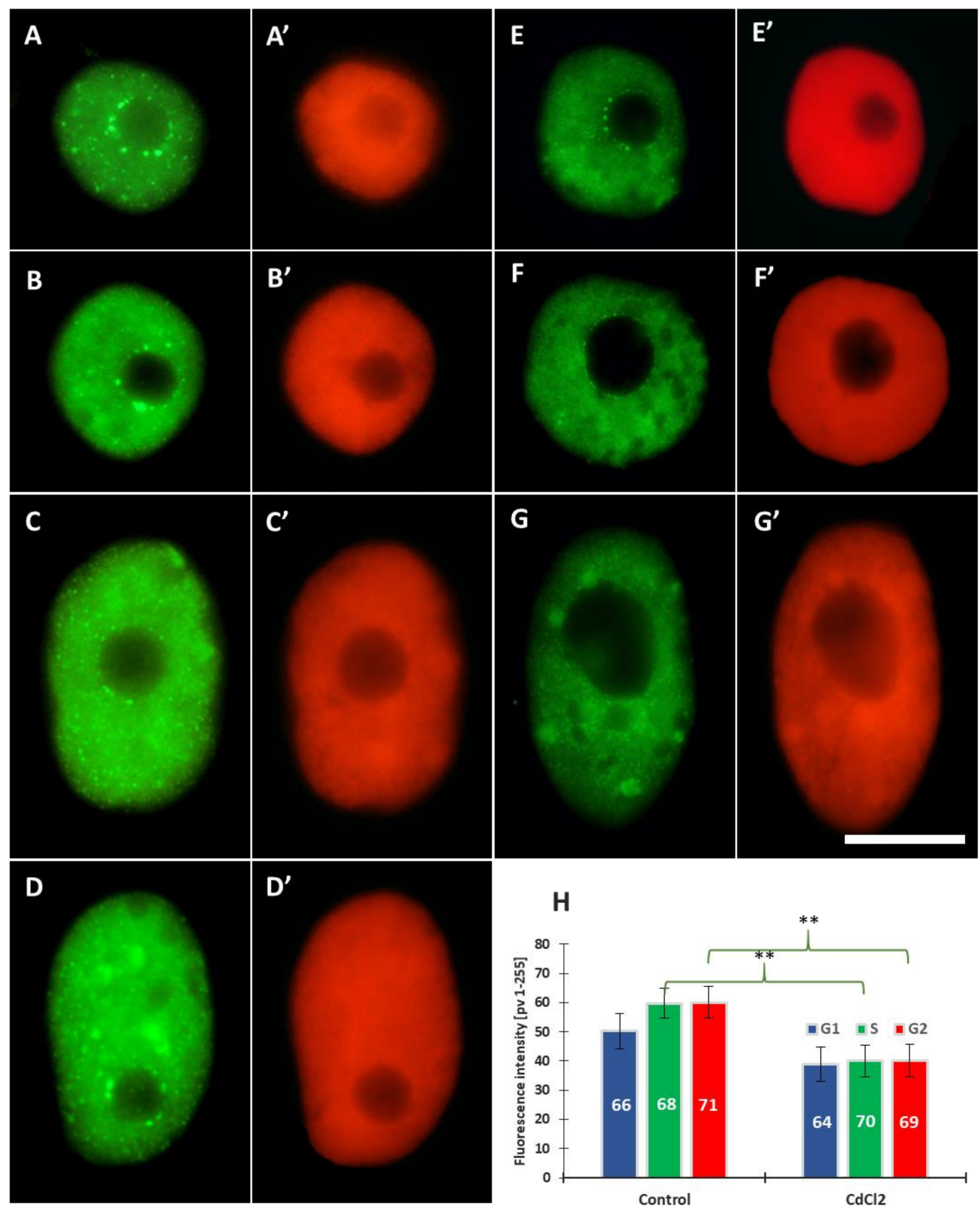

Figure 6. Immunofluorescence detection of 5-MetC in cell nuclei from the control (A-D) and $\mathrm{CdCl}_{2}$-treated root meristems $(\mathbf{E}-\mathbf{G})$ in the $\mathrm{G} 1(\mathbf{A}, \mathbf{E}), \mathrm{S}(\mathbf{B}, \mathbf{F})$, and $\mathrm{G} 2$ phases $(\mathbf{C}, \mathbf{D}, \mathbf{G})$; on the right side of each photo, the same nuclei stained with propidium iodide $\left(\mathbf{A}^{\prime}-\mathbf{G}^{\prime}\right)$; scale bar $=10 \mu \mathrm{m}$. Mean FI of 5-MetC in the G1, S, and G2 phase nuclei in the control and $\mathrm{CdCl}_{2}$-treated root meristem cells of $V$. faba $(\mathbf{H})$. Error bars represent standard deviation (SD). The numbers of cell nuclei used for immunostaining quantification are given inside the bars. Statistical significance between mean values for the intensities of H3T45Ph fluorescence (at ${ }^{* *} p<0.05$, indicated by a black asterisks) was assessed with Student's $t$-test. 

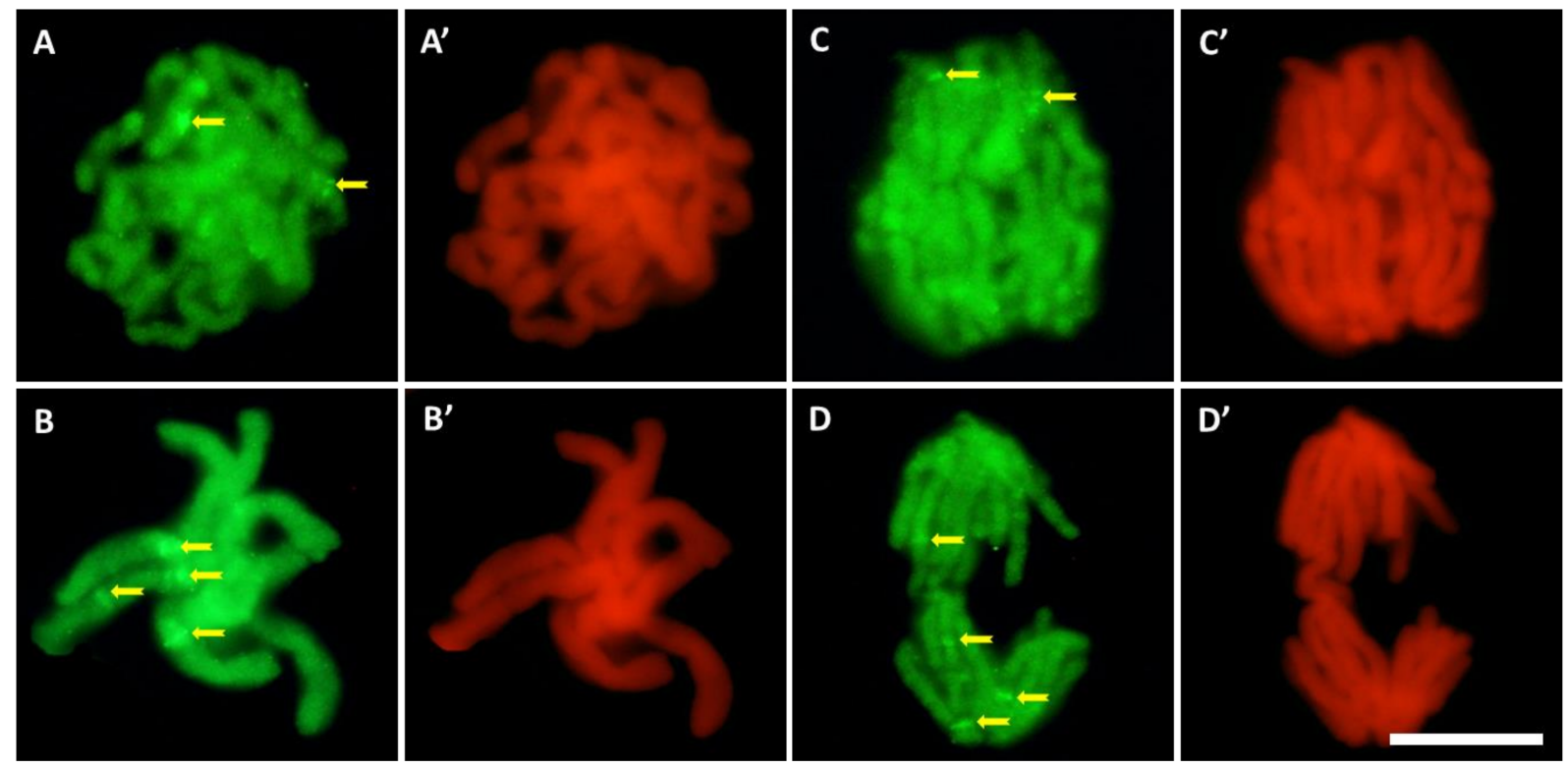

Figure 7. Immunofluorescence detection of 5-MetC during prophase (A), metaphase (B), and anaphase $(\mathbf{C}, \mathbf{D})$ in $\mathbf{C d C l}_{2}$ treated cells; bands in the pericentromeric and intercalary regions (arrows). On the right side of each photo, the same stage of mitosis stained with propidium iodide $\left(\mathbf{A}^{\prime}-\mathbf{D}^{\prime}\right)$; scale bar $=10 \mu \mathrm{m}$.

\section{Discussion}

Numerous studies have demonstrated a significant role of epigenetic mechanisms in the regulation of plant response to HM-induced stress conditions $[3,47,48]$. These mechanisms include three interconnected processes that work together in gene regulation: DNA methylation, histone modification (such as acetylation, methylation, phosphorylation, ubiquitination, biotinylation, and sumoylation), and regulatory functions mediated by non-coding RNAs [49,50]. It has been shown that: (i) epigenetic marks are used to change signaling pathways which alter cellular metabolism and, eventually, allow plants to protect themselves from possible DNA damage caused by HMs; (ii) high levels of methylation can protect DNA from endonuclease cleavage, which increases the resistance of cells to HMs; (iii) epigenetic changes serve to regulate genes responding to stress factors [3].

Our current experiments on $V$. faba root meristem cells exposed to $150 \mu \mathrm{M}$ cadmium chloride $\left(\mathrm{CdCl}_{2}\right)$ concentrated mainly on histone $\mathrm{H} 3$ modifications and epigenetic patterns of DNA methylation that are both known to be associated with the DNA replication stress conditions (RS). Accordingly, as an appropriate tool to resolve the first issue, immunofluorescence studies were chosen for the purpose of evaluating: (i) histone $\mathrm{H} 3$ acetylation on lysine 56 (H3K56Ac), which is also a key epigenetic histone modification appearing in response to DNA damages; (ii) histone H3 dimethylation on lysine 79 (H3K79Me2); (iii) histone $\mathrm{H} 3$ phosphorylation on threonine 45 (H3T45Ph).

In the control seedlings of $V$. faba, the mean number of intranuclear foci of $\mathrm{H} 3 \mathrm{~K} 56 \mathrm{Ac}$ histones was low in all phases of the cell cycle. In contrast, cells exposed to $150 \mu \mathrm{M}$ $\mathrm{CdCl}_{2}$ revealed a significant increase in the mean number of fluorescing foci, which, as demonstrated earlier after exposure to cadmium [31], seems to be associated with the appearance of DNA damage. Therefore, the obtained results confirm the theory of Masumoto et al. [21] that cells with DNA breaks exhibit a high level of H3K56 acetylation, and that the maintenance of this modification depends on DNA damage checkpoint proteins that promote the DNA repair mechanisms. Therefore, acetylation of histone H3K56 creates a favourable chromatin environment for DNA repair, and a key element in response to the DNA damage.

A distinct fraction of the genomic replication initiation sites is associated with a high frequency of dimethylation of histone H3 on lysine 79 (H3K79Me2) [39]. H3K79 undergoes mono-, di-, and tri-methylation by the enzyme DOT1 (Disruptor of Telomere Silencing 
1, [50]). DOT1-like, or DOT1L in humans [51], is involved in transcriptional elongation, DNA repair, and heterochromatin maintenance. $\mathrm{H} 3 \mathrm{~K} 79 \mathrm{Me} 2$ is particularly abundant in the late $S$ phase [52], and proper functioning of DOT1L, in cooperation with $\mathrm{H} 2 \mathrm{~B}$ ubiquitination, promotes the DNA damage checkpoint $[39,53]$. To investigate the possible association of H3K79Me2 with initiation of DNA replication, we measured H3K79Me2 enrichment levels during the $\mathrm{G1}, \mathrm{S}$, and $\mathrm{G} 2$ phases of the cell cycle in the control and $\mathrm{CdCl}_{2}$-treated cells. In untreated seedlings, the mean value of $H 3 K 79 \mathrm{Me} 2$ fluorescence was highest during DNA replication and maintained (albeit at a lower level) in the G1 and G2 phases of the cell cycle. The presence of H3K79Me2 in all phases of the cycle, not only in the S phase, can be explained by the theory of Fu et al. [39] that, during the G1 phase, the H3K79Me2 modification occurs in regions proximal to the replication origin and then extends to adjacent regions of chromatin during DNA synthesis. Then, H3K79Me2 marks, again, clusters corresponding to the initiation sites in G2, suggesting that $S$ phase-specific marks that are not related to DNA replication origins may be removed and that the origin-specific marks remain after mitosis for the next cell cycle [39]. We also observed a significant decrease in the level of $\mathrm{H} 3 \mathrm{~K} 79 \mathrm{Me} 2$ fluorescence in all cells after $\mathrm{CdCl}_{2}$ treatment, which is probably related to the decrease in the rate of DNA replication and/or to the appearance of reactive oxygen species (ROS) [31]. This result corresponds well with other studies showing that ROS can interfere with $S$ phase progression by slowing down the rate and/or inhibiting the movement of replication forks [54].

Another important modification that occurs concurrently with DNA replication is the phosphorylation of histone $\mathrm{H} 3$ on threonine 45 (H3T45Ph), which regulates numerous nuclear functions including transcription, DNA damage repair, mitosis, and apoptosis in the budding yeast Saccharomyces cerevisiae [42]. In the T45A mutant, the prolonged RS was induced by MMS (methyl methanesulphonate) by accumulation of H3T45 phosphorylation over time. As shown in our studies, $24 \mathrm{~h}$ incubation with $\mathrm{CdCl}_{2}$ induced changes in the cell cycle-related H3T45Ph. Our previous research [31] revealed that acetylation of lysine 5 in histone $\mathrm{H} 4$ (H4K5Ac) is related to the transcriptional activity and inversely correlated with nucleolar rDNA replication in the early stages of the $S$ phase. The pattern of histone $\mathrm{H} 4$ acetylation, especially as regards the nucleolar region, shows a striking similarity to the distribution of $\mathrm{H} 3 \mathrm{~T} 45 \mathrm{Ph}$ fluorescence. The spread of epigenetic markers from the G1 phase to the G2 phase in the control root meristem cells of $V$. faba allows us to suggest that phosphorylation of H3T45 may play an important regulatory role in both DNA replication and transcription. The $24 \mathrm{~h}$ incubation with $\mathrm{CdCl}_{2}$ resulted in a slight decrease in fluorescence in the G1, S, and G2 phases of the cell cycle. Therefore, it cannot be ruled out that cadmium may erode the epigenetic marks observed throughout interphase [31]. Moreover, our analyses revealed different labeling patterns of nucleolar chromatin, both in the control and after incubation of the seedlings in cadmium. A slight decrease in fluorescence within the nucleolar region may indicate its lesser susceptibility to cadmiuminduced stress [31]. It should be noted, furthermore, that, according to Jasencakova et al. [55], nucleolar territories are devoid of nucleosomes.

The chromatin landscape becomes dynamic in response to environmental signals, thus modulating DNA accessibility to factors that regulate gene expression [56]. DNA methylation is the best documented epigenetic modification involved in a number of molecular processes, such as activity of transposable elements, alternative splicing, regulation of temporal, and spatial gene expression [3,57]. Moreover, it is involved in various biological processes such as flowering and flower and leaf morphogenesis, as well as fertility regulation through gene silencing $[58,59]$. The phenomenon of DNA hypo- or hypermethylation, appearing in response to various stresses, regulates gene expression and the subsequent physiology of plants $[59,60]$. The level of DNA methylation changes in response to various metals in white clover (Trifolium repens L.), industrial hemp (Cannabis sativa L.), rape (Brassica napus), radish (Raphanus sativus L.), and rice (Oryza sativa) [61-64].

One of the aims of our present study was to analyse and compare the level of DNA methylation in the control (untreated) and cadmium-treated nuclei. An immunostaining 
method using specific antibodies against 5-MetC-modified DNA was used to determine the presence and level of DNA methylation. Compared to the control, the level of immunofluorescence of DNA methylation in roots exposed to cadmium decreased by about $30 \%$. The literature data report that $\mathrm{Cd}$ (cadmium), $\mathrm{Ni}$ (nickel), and $\mathrm{Cr}$ (chromium) cause oxidative damage [65-67], which induces DNA hypomethylation. Our earlier work [31] showed that $24 \mathrm{~h}$ treatment of seedlings with $\mathrm{CdCl}_{2}$ significantly increased $\mathrm{H}_{2} \mathrm{O}_{2}$ production. Similar results were obtained previously in studies on roots in alfalfa [68], soybean [69], BY-2 tobacco cells [70], and other plant models. Therefore, it cannot be ruled out that the phenomenon of DNA hypomethylation is related to DNA damage induced by ROS. The mechanisms by which ROS generates hypomethylation are different: (1) ROS activates endonuclease, with the consequent induction of single-stranded breaks that make DNA a weak acceptor of methyl groups; (2) metal-mediated ROS production in the vicinity of DNA generates the premutagenic adduct oxo8dG (8-oxo-20-deoxyguanosine [61,71]), resulting in a strong inhibition of methylation of adjacent cytosine residues; (3) oxidative stress induces an increase in nicotinamide (NIC) levels and poly (ADP-ribose) polymerase-1 activity [72]. In plant tissues, NIC is metabolized to trigonellin (N-methylnicotinic acid, TRIG), which has a hypomethylating effect and can induce a protective metabolism at the gene level [73]. Thus, hypomethylation can either be a precise defence mechanism by which the cell regulates gene expression, or an indirect effect of metal stress.

A number of studies have shown that DNA modifications and post-translational histone modifications play an important role in gene expression and plant development under stress factors. Two epigenetic strategies are important in plant response to heavy metal-induced stresses, including effects exerted by cadmium: (i) epigenetic markers serve as a mechanism to protect plants from possible metal ion-induced DNA damage due to random DNA methylation along the genome, and (ii) epigenetic changes are used to regulate the expression of stress-responsive genes. Some of these stress-induced modifications reset to baseline when the stress factor is gone, while some of them can be transferred as "stress memory" and inherited by the cell [74]. Thus, epigenetic memory of stress may enable plants to more effectively deal with subsequent stress factors.

Author Contributions: A.Ż. planned, carried out the experiments and prepared the final version of the article, K.W., N.G. and J.T.P. equally contributed to acquisition of the results, P.S., T.L. performed the statistical analyses. All authors have read and agreed to the published version of the manuscript.

Funding: This work was supported by a grant 2019/03/X/NZ3/00477 from the National Science Centre.

Institutional Review Board Statement: Not applicable.

Informed Consent Statement: Not applicable.

Data Availability Statement: The data presented in this study are openly available.

Acknowledgments: We thank Janusz Maszewski for preparing the final English version of the text.

Conflicts of Interest: The authors declare no conflict of interest.

\section{References}

1. Zhu, J.K. Abiotic stress signaling and responses in plants. Cell 2016, 167, 313-324. [CrossRef] [PubMed]

2. Alonso, C.; Ramos-Cruz, D.; Becker, C. The role of plant epigenetics in biotic interactions. New Phytol. 2019, 221, 731-737. [CrossRef]

3. Gallo-Franco, J.J.; Sosa, C.C.; Ghneim-Herrer, T.; Quimbaya, M. Epigenetic control of plant response to heavy metal stress: A new view on aluminum tolerance. Front. Plant Sci. 2020, 11, 602625. [CrossRef]

4. Bej, S.; Basak, J. Abiotic stress induced epigenetic modifications in plants: How much do we know? In Plant Epigenetics; Rajewski, N., Jurga, S., Barciszewski, J., Eds.; Springer: Cham, Switzerland, 2017; pp. 493-512.

5. Hirayama, T.; Shinozaki, K. Research on plant abiotic stress responses in the post-genome era: Past, present and future. Plant J. 2010, 61, 1041-1052. [CrossRef]

6. Viggiano, L.; de Pinto, M.C. Dynamic DNA methylation patterns in stress response. In Plant Epigenetics; Rajewski, N., Jurga, S., Barciszewski, J., Eds.; Springer: Cham, Switzerland, 2017; pp. 281-302.

7. Zeman, M.K.; Cimprich, K.A. Causes and consequences of replication stress. Nat. Cell Biol. 2014, 16, 2-9. [CrossRef] [PubMed] 
8. Hsu, C.-L.; Chong, S.Y.; Lin, C.-Y.; Kao, C.-F. Histone dynamics during DNA replication stress. J. Biomed. Sci. 2014, 28 , 48. [CrossRef]

9. Khurana, S.; Oberdoerffer, P. Replication stress: A lifetime of epigenetic change. Genes 2015, 6, 858-877. [CrossRef]

10. Koller, M.; Saleh, H.M. Introductory Chapter: Introducing Heavy Metals. In Heavy Metals; Saleh, H.M., Aglan, R., Eds.; IntechOpen: London, UK, 2018.

11. Rascio, N.; Navari-Izzo, F. Heavy metal hyperaccumulating plants: How and why do they do it? And what makes them so interesting? Plant Sci. 2011, 180, 169-181. [CrossRef]

12. Alengebawy, A.; Abdelkhalek, S.T.; Qureshi, S.R.; Wang, M.-Q. Heavy metals and pesticides toxicity in agricultural soil and plants: Ecological risks and human health implications. Toxics 2021, 9, 42. [CrossRef] [PubMed]

13. Navari-Izzo, F.; Quartacci, M.F.; Pinzino, C.; Dalla Vecchia, F.; Sgherri, C.L.M. Thylakoid-bound and stromal enzymes in wheat treated with excess copper. Physiol. Plant. 1998, 104, 630-638. [CrossRef]

14. Navari-Izzo, F.; Pinzino, C.; Quartacci, M.F.; Sgherri, C.L.M. Superoxide and hydroxyl radicai generation, and superoxide dismutase in PII membrane fragments from wheat. Free Rad. Res. 1999, 31, S3-S9. [CrossRef]

15. Quartacci, M.F.; Cosi, E.; Navari-Izzo, F. Lipids and NADPH-dependent superoxide production in plasma membrane vesicles from roots of wheat grown under copper deficiency or excess. J. Exp. Bot. 2001, 52, 77-84.

16. Sgherri, C.; Cosi, E.; Navari-Izzo, F. Phenols and antioxidative status of Raphanus sativus grown in copper excess. Physiol. Plant. 2003, 118, 21-28. [CrossRef]

17. Watanabe, T.; Osaki, M. Mechanisms of adaptation to high aluminum condition in native plant species growing in acid soils: A review. Commun. Soil Sci. Plant Anal. 2002, 33, 1247-1260. [CrossRef]

18. Vecchia, F.D.; La Rocca, N.; Moro, I.; De Faveri, S.; Andreoli, C.; Rascio, N. Morphogenetic, ultrastructural and physiological damages suffered by submerged leaves of Elodea canadensis exposed to cadmium. Plant Sci. 2005, 168, 329-338. [CrossRef]

19. Rascio, N.; Vecchia, F.D.; La Rocca, N.; Barbato, R.; Pagliano, C.; Raviolo, M.; Gonnelli, C.; Gabbrielli, R. Metal accumulation and damage in rice (cv. Vialone nano) seedlings exposed to cadmium. Environ. Exp. Bot. 2008, 62, 267-278. [CrossRef]

20. Hall, J.L. Cellular mechanism for heavy metal detoxification and tolerance. J. Exp. Bot. 2002, 53, 1-11. [CrossRef]

21. Masumoto, H.; Hawke, D.; Kobayashi, R.; Verreault, A. A role for cell-cycle-regulated histone H3 lysine 56 acetylation in the DNA damage response. Nature 2005, 436, 294-298. [CrossRef] [PubMed]

22. Thomson, S.; Clayton, A.L.; Hazzalin, C.A.; Rose, S.; Barratt, M.J.; Mahadevan, L.C. The nucleosomal response associated with immediate-early gene induction is mediated via alternative MAP kinase cascades: MSK1 as a potential histone H3/HMG-14 kinase. EMBO J. 1999, 18, 4779-4793. [CrossRef]

23. Hans, F.; Dimitrov, S. Histone H3 phosphorylation and cell division. Oncogene 2001, 20, 3021-3027. [CrossRef] [PubMed]

24. Mursalimov, S.; Deineko, E.; Houben, A.; Demidov, D. Histone modifications during tobacco male meiosis. Biol. Plant. 2019, 63, 681-689. [CrossRef]

25. Żabka, A.; Polit, J.T.; Maszewski, J. DNA replication stress induces deregulation of the cell cycle events in root meristems of Allium cepa. Ann. Bot. 2012, 110, 1581-1591. [CrossRef]

26. Wang, Z.; Zang, C.; Rosenfeld, J.A.; Schones, D.E.; Barski, A.; Cuddapah, S.; Cui, K.; Roh, T.-Y.; Peng, W.; Zhang, M.Q.; et al. Combinatorial patterns of histone acetylations and methylations in the human genome. Nat. Genet. 2008, 40, 897-903. [CrossRef] [PubMed]

27. Gates, L.A.; Shi, J.; Rohira, A.D.; Feng, Q.; Zhu, B.; Bedford, M.T.; Sagum, C.A.; Jung, S.Y.; Qin, J.; Tsai, M.J.; et al. Acetylation on histone H3 lysine 9 mediates a switch from transcription initiation to elongation. J. Biol. Chem. 2017, 292, 14456-14472. [CrossRef] [PubMed]

28. Alabert, C.; Groth, A. Chromatin replication and epigenome maintenance. Nat. Rev. Mol. Cell Biol. 2012, 13, 153-167. [CrossRef] [PubMed]

29. Perry, C.A.; Annunziato, A.T. Influence of histone acetylation on the solubility, H1 content and DNAse I sensitivity of newly assembled chromatin. Nucl. Acids Res. 1989, 17, 4275-4291. [CrossRef]

30. Li, Q.; Zhou, H.; Wurtele, H.; Davies, B.; Horazdovsky, B.; Verreault, A.; Zhang, Z. Acetylation of histone H3 lysine 56 regulates replication-coupled nucleosome assembly. Cell 2008, 134, 244-255. [CrossRef] [PubMed]

31. Żabka, A.; Winnicki, K.; Polit, J.T.; Wróblewski, M.; Maszewski, J. Cadmium (II)-induced oxidative stress results in replication stress and epigenetic modifications in root meristem cell nuclei of Vicia faba. Cells 2021, 10, 640. [CrossRef]

32. Branzei, D.; Foiani, M. Regulation of DNA repair throughout the cell cycle. Nat. Rev. Mol. Cell Biol. 2008, 9, 297-308. [CrossRef] [PubMed]

33. Esnault, M.A.; Legue, F.; Chenal, C. Ionizing radiation: Advances in plant response. Environ. Exp. Bot. 2010, 68, 231-237. [CrossRef]

34. Rufiange, A.; Jacques, P.E.; Bhat, W.; Robert, F.; Nourani, A. Genome-wide replication-independent histone H3 exchange occurs predominantly at promoters and implicates H3 K56 acetylation and Asf1. Mol. Cell 2007, 27, 393-405. [CrossRef]

35. Xu, F.; Zhang, K.; Grunstein, M. Acetylation in histone H3 globular domain regulates gene expression in yeast. Cell 2005, 121, 375-385. [CrossRef] [PubMed]

36. Han, J.; Zhou, H.; Horazdovsky, B.; Zhang, K.; Xu, R.-M.; Zhang, Z. Rtt109 acetylates histone H3 lysine 56 and functions in DNA replication. Science 2007, 315, 653-655. [CrossRef] 
37. Han, J.; Zhou, H.; Li, Z.; Xu, R.-M.; Zhang, Z. Acetylation of lysine 56 of histone H3 catalyzed by RTT109 and regulated by ASF1 is required for replisome integrity. J. Biol. Chem. 2007, 282, 28587-28596. [CrossRef] [PubMed]

38. Tsubota, T.; Berndsen, C.E.; Erkmann, J.A.; Smith, C.L.; Yang, L.; Freitas, M.A.; Denu, J.M.; Kaufman, P.D. Histone H3-K56 acetylation is catalyzed by histone chaperone-dependent complexes. Mol. Cell. 2007, 25, 703-712. [CrossRef]

39. Fu, H.; Maunakea, A.K.; Martin, M.M.; Huang, L.; Zhang, Y.; Ryan, M.; Kim, R.G.; Lin, C.M.; Zhao, K.; Aladjem, M.I. Methylation of histone $\mathrm{H} 3$ on lysine 79 associates with a group of replication origins and helps limit DNA replication once per cell cycle. PLoS Genet. 2013, 9, e1003542. [CrossRef]

40. Driscoll, R.; Hudson, A.; Jackson, S.P. Yeast Rtt109 promotes genome stability by acetylating histone H3 on lysine 56. Science 2007, 315, 649-652. [CrossRef]

41. Wurtele, H.; Kaiser, G.S.; Bacal, J.; St-Hilaire, E.; Lee, E.-H.; Tsao, S.; Dorn, J.; Maddox, P.; Lisby, M.; Pasero, P.; et al. Histone H3 Lysine 56 acetylation and the response to DNA replication fork damage. Mol. Cell Biol. 2012, 32, 154-172. [CrossRef]

42. Hurd, P.J.; Bannister, A.J.; Halls, K.; Dawson, M.A.; Vermeulen, M.; Olsen, J.V.; Ismail, H.; Somers, J.; Mann, M.; Owen-Hughes, T.; et al. Phosphorylation of histone H3 Thr-45 is linked to apoptosis. J. Biol. Chem. 2009, 284, 16575-16583. [CrossRef]

43. Baker, S.P.; Phillips, J.; Anderson, S.; Qiu, Q.; Shabanowitz, J.; Smith, M.M.; Yates, J.R.; Hunt, D.F.; Grant, P.A. Histone H3 Thr 45 phosphorylation is a replication-associated post-translational modification in S. cerevisiae. Nat. Cell Biol. 2010, 12, $294-298$. [CrossRef]

44. Unyayar, S.; Celik, A.; Cekic, F.O.; Gozel, A. Cadmium-induced genotoxicity, cytotoxicity and lipid peroxidation in Allium sativum and Vicia faba. Mutagenesis 2006, 21,77-81. [CrossRef]

45. Souguir, D.; Ferjani, E.E.; Ledoigt, G.; Goupil, P. Sequential effects of cadmium on genotoxicity and lipoperoxidation in Vicia faba roots. Ecotoxicology 2011, 20, 329-336. [CrossRef]

46. Feulgen, R.; Rossenbeck, H. Mikroskopisch-chemischer nachweis einer nucleinsäure vom typus der thymonucleinsäure und die darauf beruhende elective farbung vom zelikernen in mikroskopischen präparaten. Zts. Phys. Chem. 1924, 135, $203-248$.

47. Sudan, J.; Raina, M.; Singh, R. Plant epigenetic mechanisms: Role in abiotic stress and their generational heritability. 3 Biotech 2018, 8, 172. [CrossRef] [PubMed]

48. Chang, Y.N.; Zhu, C.; Jiang, J.; Zhang, H.; Zhu, J.K.; Duan, C.G. Epigenetic regulation in plant abiotic stress responses. J. Integrat. Plant. Biol. 2020, 62, 563-580. [CrossRef] [PubMed]

49. Akhter, Z.; Bi, Z.; Ali, K.; Sun, C.; Fiaz, S.; Ullah Haider, F.; Bai, J. In response to abiotic stress, DNA methylation confers epigenetic changes in plants. Plants 2021, 10, 1096. [CrossRef]

50. Lacoste, N.; Utley, R.T.; Hunter, J.M.; Poirier, G.G.; Cote, J. Disruptor of telomeric silencing-1 is a chromatin-specific histone H3 methyltransferase. J. Biol. Chem. 2002, 277, 30421-30424. [CrossRef] [PubMed]

51. Frederiks, F.; Tzouros, M.; Oudgenoeg, G.; van Welsem, T.; Fornerod, M.; Krijgsveld, J.; van Leeuwen, F. Nonprocessive methylation by Dot1 leads to functional redundancy of histone H3K79 methylation states. Nat. Struct. Mol. Biol. 2008, 15, 550-557. [CrossRef]

52. Zhou, H.; Madden, B.J.; Muddiman, D.C.; Zhang, Z. Chromatin assembly factor 1 interacts with histone H3 methylated at lysine 79 in the processes of epigenetic silencing and DNA repair. Biochemistry 2006, 45, 2852-2861. [CrossRef] [PubMed]

53. Giannattasio, M.; Lazzaro, F.; Plevani, P.; Muzi-Falconi, M. The DNA damage checkpoint response requires histone H2B ubiquitination by Rad6-Bre1 and H3 methylation by Dot1. J. Biol. Chem. 2005, 280, 9879-9886. [CrossRef] [PubMed]

54. Wilhelm, T.; Ragu, S.; Magdalou, I.; Machon, C.; Dardillac, E.; Techer, H.; Guitton, J.; Debatisse, M.; Lopez, B.S. Slow replication fork velocity of homologous recombination-defective cells results from endogenous oxidative stress. PLoS Genet. 2016, 12, e1006007. [CrossRef] [PubMed]

55. Jasencakova, Z.; Meister, A.; Walter, J.; Turner, B.M. Schubert I Histone acetylation of euchromatin and heterochromatin is correlated with replication rather than with transcription. Plant. Cell 2000, 12, 2087-2100. [CrossRef]

56. Berr, A.; Shafiq, S.; Shen, W.H. Histone modifications in transcriptional activation during plant development. Biochim. Biophys. Acta 2011, 1809, 567-576. [CrossRef]

57. Zhang, X.; Yazaki, J.; Sundaresan, A.; Cokus, S.; Chan, S.W.L.; Chen, H.; Henderson, I.R.; Shinn, P.; Pellegrini, M.; Jacobsen, S.E.; et al. Genome-wide high-resolution mapping and functional analysis of DNA methylation in Arabidopsis. Cell 2006, 126, 1189-1201. [CrossRef] [PubMed]

58. Zhang, M.; Kimatu, J.N.; Xu, K.; Liu, B. DNA cytosine methylation in plant development. J. Genet. Genom. 2010, 37, 4. [CrossRef]

59. Shafiq, S.; Khan, A.R. Plant Epigenetics and Crop Improvement. In Plant Omics: The Omics of Plant Science; Barh, D., Khan, M.S., Davies, E., Eds.; Springer: New Delhi, India, 2015; pp. 157-179.

60. Peng, H.; Zhang, J. Plant genomic DNA methylation in response to stresses: Potential applications and challenges in plant breeding. Prog. Nat. Sci. 2009, 19, 1037-1045. [CrossRef]

61. Aina, R.; Sgorbati, S.; Santagostino, A.; Labra, M.; Ghiani, A.; Citterio, S. Specific hypomethylation of DNA is induced by heavy metals in white clover and industrial hemp. Physiol. Plant. 2004, 121, 472-480. [CrossRef]

62. Yang, J.L.; Liu, L.W.; Gong, Y.Q.; Huang, D.Q.; Wang, F.; He, L.L. Analysis of genomic DNA methylation level in radish under cadmium stress by methylation-sensitive amplified polymorphism technique. J. Plant. Physiol. Mol. Biol. 2007, 33, $219-226$.

63. Filek, M.; Keskinen, R.; Hartikainen, H.; Szarejko, I.; Janiak, A.; Miszalski, Z.; Golda, A. The protective role of selenium in rape seedlings subjected to cadmium stress. J. Plant. Physiol. 2008, 165, 833-844. [CrossRef] 
64. Feng, S.J.; Liu, X.S.; Tao, H.; Tan, S.K.; Chu, S.S.; Oono, Y.; Zhang, X.D.; Chen, J.; Yang, Z.M. Variation of DNA methylation patterns associated with gene expression in rice (Oryza sativa) exposed to cadmium. Plant. Cell Environ. 2016, 39, 2629-2649. [CrossRef]

65. O'Brien, P.; Salacinski, H.J. Evidence that the reactions of cadmium in the presence of metallothionein can produce hydroxyl radicals. Arch. Toxicol. 1998, 72, 690-700. [CrossRef]

66. Boominathan, R.; Doran, P.M. Ni-induced oxidative stress in roots of the Ni hyperaccumulator, Alyssum bertolonii. New Phytol. 2002, 156, 205-215. [CrossRef] [PubMed]

67. Dixit, V.; Pandey, V.; Shyam, R. Chromium ions inactivate electron transport and enhance superoxide generation in vivo in pea (Pisum sativum L. cv. Azad) root mitochondria. Plant. Cell Environ. 2002, 25, 687-693. [CrossRef]

68. Ortega-Villasante, C.; Hernández, L.E.; Rellán-Álvarez, R.; del Campo, F.F.; Carpena-Ruiz, R.O. Rapid alteration of cellular redox homeostasis upon exposure to cadmium and mercury in alfalfa seedlings. New Phytol. 2007, 176, 96-107. [CrossRef] [PubMed]

69. Pérez-Chaca, M.V.; Rodriguez-Serrano, M.; Molina, A.S.; Pedranzani, H.E.; Zirulnik, F.; Sandalio, L.M.; Romero-Puertas, M.C. Cadmium induces two waves of reactive oxygen species in Glycine max (L.) roots. Plant. Cell Environ. 2014, 37, $1672-1687$. [CrossRef]

70. Olmos, E.; Martinez-Solano, J.R.; Piqueras, A.; Hellin, E. Early steps in the oxidative burst induced by cadmium in cultured tobacco cells (BY-2 line). J. Exp. Bot. 2003, 54, 291-301. [CrossRef] [PubMed]

71. Briat, J.F.; Lebrun, M. Plant responses to metal toxicity. Comptes Rendus de l'Academie des Sciences, Serie III. Sci. Vie/Life Sci. 1999, 322, 43-54.

72. Hageman, G.J.; Stierum, R.H. Niacin, poly (ADP-ribose) polymerase-1 and genomic stability. Mutation Res. 2002, 475, 45-56. [CrossRef]

73. Berglund, T. Nicotinamide, a missing link in the early stress response in eukaryotic cells: A hypothesis with special reference to oxidative stress in plants. FEBS Lett. 1994, 351, 145-149. [CrossRef]

74. Wibowo, A.; Becker, C.; Marconi, G.; Durr, J.; Price, J.; Hagmann, J.; Papareddy, R.; Putra, H.; Kageyama, J.; Becker, J.; et al. Hyperosmotic stress memory in Arabidopsis is mediated by distinct epigenetically labile sites in the genome and is restricted in the male germline by DNA glycosylase activity. Elife 2016, 31, e13546. [CrossRef] 